\title{
КУЛТУРНА ИНДУСТРИЈА И ПОПУЛАРНИ КАПИТАЛ
}

\begin{abstract}
Овај рад бави се анализом савременог конзумеристичког друштва. Кад новац постане мера свих ствари, културна динамика све више поприма облике трговачких односа. Због тога долази почиње да преовлађује такозвана популарна, ниска култура, која се лакше рекламира и продаје, и веома је профитабилна. У том контексту, висока култура почиње да финансијски зависи од ниске културе. Како су новчани токови обема заједнички, то значи уплив у културу чинилаца који са њом никакве везе немају, попут индустријалаца, бизнисмена, магната. Рад даље указује на конкретан пример Србије у којој је сличан тренд комерцијализације културе нарочито узео маха након Титове смрти. Конзументска, ниска култура одиграла је и своју улогу у време уочи и током распада Југославије, везујући се за растући талас национализма.
\end{abstract}

Кључне речи: висока култура, ниска култура, новац, конзумеризам, кич, национализам

Степен сложености друштва и разноврсност индивидуалних улога у њему подстичу културне новине и мењање образаца (Клосковска 2005: 201); што је друштво богатије то су услови за културну (ре)продукцију бољи и бројнији. Развој културних форми подразумева умножавање сврха и циљева, али и средстава потребних за њихово остварење. Неопходна економска мотивација културног сектора не мора увек бити и покретачка. Успутна улагања, са циљем обликовања постојећих популарних форми, или принцип $\bar{u} о с \bar{u}$ инверзије начини су да се већ наглашени обриси културне идеологије измене и као такви утемеље. У том мконтескту проблем улоге новца као уложеног капитала у еволуцију културних форми може се пратити кроз процес формирања тржишне вредности производа културе и мера платежног концепта који одређује његову уметничку димензију.

Продуктивна снага у рукама је појединаца који моћ новца користе у сврху помирења његове рационалне и ирационалне димензије. Ирационални сегменти економског система резултат су пројектоване 
дисхармоније, контролисаног хаоса, идеологизације знања. Зато проучавање економских законитости захтева интердисциплинарни приступ, као што проучавње културе у том контексту остаје непрецизно без дефинисања основних економских претпоставки. Дакле, када уз помоћ социјално-економског дискурса објашњавамо и разумевамо културне појаве, феномене, ми их расветљавамо помоћу њих самих (Кајтез 2006: 7).

Када је реч о савременим појавама друштвено-културног карактера, које није лако објаснити, значајно место заузима новац. Као феномен он има важну улогу у систему вредности и немогуће га је одвојити од савремене културне производње. Уско је повезан са осећајем и значењем моћи, због чега се често ова два термина изједначавају. Колико је њихова међузависнот утицала на језик постојећег и стварање новог културног правца могуће је пратити кроз политику имиџа као изузетно сложеног производа модерног музичког израза.

У сваком сегменту популарног улога капитала је пресудна, али се различито поставља и третира. На југословенској и српској сцени популарне културе, у рок музици и новом таласу, новац делује из позадине и привидно нема велики значај. Филозофска концепција ове музике не подразумева наглашену естетику, али се не може замислити без квалитетне продукције, музичке опреме, текстова и одличних музичара. Чињеница да је група Бијело gyїме у периоду од 1975-1979. године снимила свој други, трећи и пети албум у Лондону са тада познатим музичким продуцентом Нилом Харисоном (Јањатовић 1998: 32) говори колико је током социјалистичке културне политике улагано у популарну музику. Осамдесетих година, вођа групе, Горан Бреговић, оснива сопствену музичку продукцијску кућу у којој наставља рад и већ тада има капитал који је дошао као последица скривених политичких интереса због присуства на великом југословенском тржишту. Бреговић „купује” ВИС Иgоле, који се јавности представљају кроз шарм независне продукције часописа Вияици (продуценти Драган Папић и Александар Петровић) настале као један од резултата опсежног пројекта критике технологије, али којима независна продукција не може да обезбеди излазак на тржиште. Бреговић снагом друштвеног капитала који стоји иза њега преузима визију Иgола, насталу из пројекта Дечащи који је неколико година концептуално и визуелно раз- 
рађиван у Вияищима (да би се потом придружила и друга гласила), и прави од њих сурогат иницијалне идеје, комерцијалну представу. Он тиме потврђује потенцијал своје продукције, јер у њу уграђује свежу енергију Новог таласа коју доноси састав Иgоли усмерену Вияицима ка идеји показивања да појава, ма колико празна, у технолошком друштву има приоритет у односу на садржај и квалитет. ${ }^{1}$ Пре тога је најмање улагано у визуелни аспект који је, по свему судећи, одговарао визуелној филозофији рок музике. ВИС Иуоли вођени Д. Папићем и постављени у контекст који је А. Петровић дао Речником иехнолойје, као врхунским изразом пројекта критике технолошког света, потпуно другачије прилазе визуелизацији музике, што се поред квалитетне продукције огледа и у улагању у изглед, чему је значајно допринео идеолошки концепт њихове музике. Међутим, у Бреговићевом комерцијалном кључу они, уз неке интелектуалне трзаје, убрзо постају бледа копија Бијелог дугмета. Ту постаје видно да се Бреговићево стваралачко преиспитивање културне матрице у осетљивом периоду после Титове смрти своди на симулацију, пуки комерцијални захват. Разарањем критичке свести садржане у пројекту Иgоли, Бреговић је непосредно угушио једну могућност концептуалног преиспитивања друштвених токова и допринео разорној стихији против које се привидно борио.

Кулминација новца и моћи у музици појављује се деведесетих година у виду турбо-фолка. Поред поп, рок и лајт панка (Light Punk) на југословенској сцени, Бреговић се клонира и у овај музички правац, привидно супротан од Новог таласа Иgола. Ту такође, он у потпуности користи моћ визуелне представе и, редукујући музички и продукцијски аспект, од имиџа непосредно прави капитал што и јесте била главна експериментална идеја на којој су у Вияицима створени Иgоли. Будући да је састављен од различитих визија елитног и модерног, имиџ коме је музика само средство подразумева широк (ре) интерпретативни значењски простор. У оваквом контексту новац је полазна и непроменљива идеја која као магнетни стуб на себе привлачи бројне субконцепте, као на пример концепт уметничке, естетске или статусне димензије популарног израза. Њихова међузависност

1 Више о пројектима окупљених око концепта Речника технологије, Дечака, Идола... види на http://recniktehnologije.wordpress.com/category/uvod-i-registar/ 
индиректно показује да концепт новца утиче на нова правила културне политике чија идеологија одговара количини уложеног капитала.

Као што ни било коју појаву није могуће посматрати независно од утицаја других, мање или више значајних, тако ни новац у контексту уложеног капитала (културне индустрије) није могуће издвојити из сложеног корпуса историјског, психолошког, естетског, религијског значења. Важно је истаћи да на нивоу манипулативног дејства он функционише мотивационо и двосмерно: ка конструктивним и ка деструктивним друштвеним акцијама. Колико је та мотивација значајна у оба смера може се видети на целокупној културној сцени, а посебно у популарној музици деведесетих у Србији. Стилска једноликост онемогућила је фер-плеј у све напетијој тржишној утакмици у којој су све снаге биле уперене ка демонстрацији богатства као најјачем социјалном, психолошком и статусном адуту. Културна омасовљеност у виду „масовне индивидуализације” подразумевала је задовољавање захтева понуђеног културног модела, док је, истовремено, индивидуално било изражено кроз потребу за украшавањем, театралношћу, завођењем, игром, показивањима, трансцендирањима, опсценошћу.

На овом комуникационом нивоу оствариван је сурови тржишни промет културним производима, па је унутар посматраног феномена новца немогуће заобићи феномен размене чија су правила одређена успостављањем система вредности (Кајтез, 2006: 10). Феномен размене, било да је економски, религијски, естетички, семантички, синтаксички, метафизички, емотивни, разумљив је кроз људску егоистичну, у природи комуникације архетипски утемељену потребу за симболичком разменом. Омасовљене размене истих производа доводе до засићења тржишта и ствара се потреба за понудом нових културно-робних добара. Сваки нови производ, међутим, резултат је потребе за померањем постојећих граница. На тај начин формирани комуникативни системи успостављају нове односе међусобне комуникације, што утиче на промену начина тумачења добијених информација, а све заједно, посматрано на нивоу значења, обликује нову културолошко-комуникативну заједницу. Новоприхваћени симболи представљају средства за споразумевање, а медији пружају нове могућности (не)разумевања понуђених садржаја.

Свака размена добара уједно је и прилика за зараду. У тржишни систем производње и потрошње културе укључен је велики број 
посредника усредсређених на преношење порука, значења новца од извођача до публике и обрнуто. Трансакције информација подразумевају како симболичку тако и економску размену. Било да је интелектуална, економска, религијска, емотивна, трансакција не може да избегне свој шпекулативни карактер. Уколико се пође од тога да је циљ шпекулације присвајање „вишка” туђег добра/новца у своју корист, јасно је да сваки производ може бити искоришћен у шпекулативне сврхе. Производи културне индустрије у виду комерцијалних лаких нота, шоу бизниса, професионалног спорта, моде, извор су великог капитала, што отвара простор за присвајање добара као резултата заслуге неког другог. Роба индустрије културе, тако, постаје предмет шпекулација, чиме се умањује карактер и најмањег њеног уметничког значаја. Због економског и привредног положаја Србије постоји склоност да сваку шпекулацију називамо успешним послом и оправдамо тренутним потребама тржишта, па се овакве појаве сматрају легалним предузетничким радњама.

Правила тржишне економије важе и у сфери културне индустрије, али шта заиста културном добру одређује производну вредност? На економском тржишту понуда и потражња међусобно су сразмерне. Робни стандарди произашли су из потреба конзумената, што утиче на прихватање робе без отпора. Чињеница да „све има своју цену” подједнако је присутна како на једноставнијим тако и на развијенијим нивоима друштвеног живота. У складу са тим, продукција добара културне индустрије одговара захтевима тржишта којем је намењена, а то „тржиште” одређено је социјално-економским статусом конзумената. На вишим друштвеним нивоима и у сложенијим облицима социјалног живота дешава се исто што и на нижим, али са разликом у квалитету произведене робе и у бројности публике којој је та роба намењена.

Пратећи инерцију друштва појединац својим интересима нуди сурогате робе као разменског еквивалента. Иако му нису потребни, он их прихвата и легитимише, посебно када су њени промотери утицајни чланови заједнице или општеприхваћени систем вредности. Новац као мотивационо средство недвосмислено утиче на продукцију културних производа, њихово легитимисање од стране друштва, као и на глобални развој културне индустрије. Моћ новца сразмерна је ин- 
тезитету производње. Међутим, друга страна његове моћи лежи у извору благостања и страха. Тиме што омогућава робну размену, новац је и онеспособљава уколико га нема. Новац, тако, поред ваздуха, хране и воде, постаје један од основних егзистенцијалних фактора. Повезаност новца са страхом од смрти често је изједначена са страхом од незапослености, што даље значи да је та бојазан економско-егзистенцијалне природе. Незапосленост је једнака престанку економске, симболичке, емотивне, религијске, интелектуалне, културне комуникације - престанак размене.

У контексту новца као феномена и његових пратећих подпојава деведесете године у Србији изгледају као колективна бојазан од престанка размене на свим комуникацијским нивоима. Страх од културне и цивилизацијске изопштености довео је до праксе симулирања боље стварности коју је стварала културна индустрија. Престанак размене значио би живот у изолацији који је у потпуности једнак осећају усамљености који је, опет, једна врста смрти. У крајњој инстанци, страх од смрти је страх од престанка сваке комуникације. (Кајтез 2006:12).

У савременој антропологији феномен размене препознат је и као регулатор међуљудских односа. Анализом структуре сродства примитивне заједнице Леви-Строс примећује да се механизам интеграције заснива на размени која се испољава у три основна облика: размена жена склапањем бракова, размена робе, размена речи у процесу језичког споразумевања. Према овој подели, сваки поменути тип размене се односи на знакове, па се тако идентификује са семиотичким процесима споразумевања, што значи да су сви размењиви елементи - знакови. Осим робе, улогу знакова имају и жене. Са аспекта структуралне антропологије и организације примитивних људских заједница, жена је организационо и просторно везана за структуру клана.

Уколико се у овом контексту осврнемо на Бодријарову идеју да је свака потрошња размена из чијег се друштвеног карактера закључује да се ради о размени значења (Бодријар 1981: 1-7) онда се и жена, са свим значењима карактеристичним за одређени тренутак и улогу, може тумачити као комплексни друштвено-културни феномен са тенденцијом размене. На тај начин формирано семантичко поље нуди бескрајан низ тумачења, где се чак и претходно поменути иресйанак размене изједначава са смрћу и формира око жене. Феномен 
ратничког шика или у модификованим условима насталог турбо-фолка, представљао је прибежиште у паралелну реалност која је нудила вештачки продужетак живота. Нове друштвено-културне вредности одговарале су свим социјалним слојевима који су били обавијени ауром егзистенцијалне, разменске несигурности. На тај начин се објашњава неусклађеност употребне и прометне вредности са реалном, стилском која одређује економски аспект робе.

Да би се остварила размена пожељно је да сваки субјект мисли да тим процесом добија више него што даје, што је основни разлог због којег пристаје на њу. У контексту конзумирања вишезначне и вишеслојне идеологије турбо-фолка, с једне стране, значило би да само једна песма (у аудио-визуелној форми) нуди пожељан стил облачења, понашања, вербалног и гестовног изражавања, стила, веровања. Тако се потрошач осећа као неко ко профитира у културно-робној размени у којој, из различитих комуникативних сфера, узима само оно што му је потребно. Са друге стране, начин на који је та иста песма прихваћена у форми робе условљава понашање појединца као дела друштва које, опет, постаје његова рефлексија, али и рефлексија самог популарног облика кроз његове појавне вредности. Дакле, онај који купује то ради зато што верује да добија и да збир вредности након ове размене треба да буде већи него пре но што је до ње дошло.

Правила према којима функционише културна индустрија у постсоцијалистичкој Србији деведесетих усклађена су према друштвено-културним вредностима хиперинфлације која је значила вртоглаву промену постојећег економског система. У економским наукама овај термин означава „преко мере, претерано штампање и пуштање у оптицај новчаница за плаћање” (Вујаклија 2002: 353). На плану културног и националног потврђивања, деведесетих долази до хиперинфлације традиционалних вредности које се умножавају према свакодневним потребама и захтевима савременог српског друштва. Њихова продукција зависила је и од водеће идеолошке концепције јер је прилагођавана стварању српског идентитета. Акумулација нових културно пожељних елемената и кодова према којима се заједница препознаје била је брза, масовна и на крају девалвирајућа.

Тржишну вредност продукције значења као робе, производа (културне) индустрије, одређује уложени капитал. Било да је у новцу, 
интелекту или у промени физичког изгледа промотера нове робе, капитал има улогу да редукује људске идеје, мотиве и жеље на пасивне и инертне форме погодне за манипулацију (Кајтез 2006: 118). Симболичко насиље овог типа резултира наметањем воље „појединца” изражене кроз привилеговану мањину финансијско-политичке елите у поткупљивању културног естаблишмента.

Уколико се посматра аспект моћи структура које имају највећи утицај на промене у свету који нас окружује, паралелно ће се издвојити индустријски и културни монопол. Овај други је слаб и зависан од првог у чијем је поседу највећи део финансијског капитала. Тако плејада генералних директора сектора индустрије, челика, струје, банака постаје налогодавац нових облика културног израза. Културни сектор, у који је уложен новац, мора се потрудити да удовољи налогодавцима који често, усмеравајући потребе тржишта према сопственом укусу, постају главни креатори нових културних форми. Истина модерног времена састоји се у томе да је наш део Земље утонуо у варварство јер се власништво над средствима за производњу одржава силом (Брехт 1979: 174).

Популарна музика, за разлику од осталих облика симболичке уметности, излази из формализованих оквира система културе, јер је и настала у специфичним условима осликавајући друштвени и културни карактер својих ствараоца. Како су њени центри били у црначким гетима, унутар периферних друштвених структура у милионским градовима, у мање развијеним срединама могућност контакта са комерцијализованим обликом забаве била је несметана. Сваки нови, другачији и неформални производ може, као део културне индустрије, имати веома широки домет деловања.

Културна индустрија није производ савременог доба јер сви њени елементи постоје од како постоји забава. Разлика између уметничке, узвишене и модерне музике намењене забави примећена је још пре једног и по миленијума. Идеја о постојању онога што се данас назива културном индустријом антиципирана је у условима који су много мање били индустријски, а још мање модерни. Једна од њених основних карактеристика била је и јесте недостатак „стила”, јер принципи културне индустрије постављају имитацију за функционални основ, чиме се њени производи удаљавају од оригиналних форми елитне културе и уметности (Хоркајмер-Адорно 1969: 136). 
Већ и према класичној речничкој дефиницији индустрија подразумева производну делатност, посебно производњу на велико, прераду сировина и поделу рада (Вујаклија 2002: 334). Стваралачки процеси културне индустрије нуде објашњење како настају и на који начин се културни производи прилагођавају савременом начину живота. Тржишна потражња условила је масовну прераду „културних сировина" што не оставља простор за стил и концепт уметничког. Модерна технологија омогућила је да се културна индустрија лако поистовети са уложеним капиталом, па је и културу, као производ, могуће транспоновати у сферу масовне потрошње. Као готова роба, производ примарне култуне сировине, појављује се „лака” уметност која је друштвена нечиста савест озбиљне уметности (ХоркајмерАдорно 1969: 141). Нова форма интелектуалног пражњења настала је тако што су се под исту формулу свели сви наизглед непомирљиви елементи културе, уметности и разоноде.

Производи модерног уметничког израза део су глобалне савремене сцене на којој је сваки потез у служби новог „театра” обликован новом социолошком ситуацијом. Форме популарне и елитне уметности скоро у потпуности зависе од великих апарата, опере, позорнице, штампе, који настају и нестају захваљујући друштву које од њих прихвата само оно што га тренутно одражава и ничим не угрожава његову функцију - разоноду (Брехт 1979:59).

За разлику од рок музике и новог таласа, турбо-фолк се, пратећи савремену друштвену динамику, појављује као чист производ примарне културне сировине чији се стил заснива на споју неспојивих елемената који заједно функционишу према правилима утврђиваним „у ходу” и према потреби. Неће бити погрешно ако се за ову музику каже да је истовремено савремени појавни облик, музички правац, жанр, стил, начин живота, „филозофија”, јер према диверзитету значења која нуди он то и јесте. Производи лаке забаве не захтевају посебну интелектуалну активност појединца из тог разлога што са̂м производ подразумева реакцију учесника која није резултат размишљања. Комуникација се одвија сигналима, кратким порукама пошиљаоца ка примаоцу. Интерпретација таквих порука једнозначна је тако да појединац према начину размишљања постаје сличан сваком другом појединцу припаднику масе. На тај начин сви постају део „ма- 
совне индивидуализације”, односно исте целине у којој су привидно самостални.

Форме лаке уметности, забаве и разоноде, појављују се као значајни манипулативни идеолошки алати који их чине нераздвојним од понашања гомиле. Иако је појава турбо-фолка деловала изненађујуће и шокантно, она је заправо била плод дуго времена припреманог тла. Изненадна и велика популарност чини га делом масе чија су уверења одређена посредним и непосредним друштвено-културним чиниоцима. У прилагођавању идеологији деведесетих кроз популарну музику значај посредних чинилаца је у припремању терена за идеје које у тренутку појављивања само делују као резултат спонтаног, а заправо су само површински ефекат којем претходи дуготрајан рад (Лебон 2007: 51). Захваљујући непосредним чиниоцима, чија је улога слична деловању идеолошких ефеката, дешавају се промене у актуелном значењском контексту.

Део представе турбо-фолка утемељен је на промоцији идеја које су подстицале менталитет масе и смеру национално мотивисаних сукоба. Када се у аудио-визуелној реклами за песму једног од познатих певача појави певач лично у војној униформи и око њега оружје, то је јасан знак да је (не)посредно присутна сила као један од идеолошких израза. Следбеници овог музичког жанра схватиће то као легитиман начин живота у ратним условима и неће се устручавати од употребе оружја у сврху која им у одређеном тренутку одговара. Развија се свест о томе да су у свакодневном животу они ти који ће у име националног освешћења или трпети силу или бити насилници. Цензура не постоји јер је количином уложеног капитала безусловно онемогућена, а сваки индивидуални отпор у том правцу унапред је сломљен.

Тајна културне индустрије лежи у томе да она производи фикцију и продаје је по веома високој цени. Она не нуди новац и богатство већ представу да је све то на дохват руке, да је реално, да постоји. Непрестано обећава потрошачима оно што никако не намерава да пружи, јер јарке боје, богатство, сјај, позната имена и велика обећања на крају постају само величање сиве свакодневице од које се жели побећи (Хоркхајмер-Адорно 1969: 145). Тако популарне певачице деведесетих промовишу не само свој професионални већ и приватни живот као луксузан и пун сјаја. Ни у једном од њих нема места 
за неуспех и незадовољство. Ту се сусрећу два различита друштва, једно сиромашно и немоћно пред насилно јачим и друго, преко ноћи економски оснажено које намеће нове културне вредности. Да би се међусобно пратили, слабије друштво прихвата нова правила и почне да верује у представу живота коју је створила нова културна елита. Тако се оне преостале вредности код савесне мањине постепено губе и настаје ново хибридно уобличено друштво. Певачице постају узори младима, а њихови животни путеви из удаљених села до велеграда и самог чела културног дешавања имају призвук остварења „америчког сна”. На том путу сваку од њих прати мушкарац, успешан бизнисмен који зна како да искористи актуелне услове и омогући адекватан профит. Огромне количине новца улагане су у бирање текстописаца, продукцијских кућа, радио станица, стилиста, режисера видео спотова, пластичних хирурга не би ли фикција изгледала што реалније. Свака нова идеја померала је границе, а посебно су у сфери естетике разбијени бројни табуи. Изазовне груди, наглашене усне, надоградња косе, ноктију, постали су естетски синоними за певачице и потврдили да је за сцену популарне народне музике важо исто што и за саму културну индустрију - она је порнографска и срамежљива (Хоркхајмер-Адорно 1969:145).

Индустрија културе често има за циљ да безусловно хероизира личности чије су интелектуалне и професионалне способности недовољне да се одупру њеним идејама. Представе које су свакој од тих личности намењене у циљу подржавања ширег идеолошког плана замишљене су да делују реално, блиско и остварљиво свакоме ко је за њих заинтересован. Циљна група је „грађанин”, индивидуа која делује према правилима масе чији је члан и свесно тражи бег од реалности приватног и пословног живота. Усамљеност и незадовољство утицали су на ломљивост његовог карактера, што истовремено представља критичну тачку друштва неопходну за развој потрошње добара културне индустрије.

Специфичност турбо-фолка је и у томе да је прихваћен једнако од свих друштвених слојева независно од степена образовања. Као конзументи ове културе на истом нивоу су били грађани и са најнижим и са највишим образовним квалификацијама. Слике и представе које је нудила певачица као транспарентни емитер вредности и значења тумачене су на свим друштвеним нивоима подједнако. 
Основни порив, свакако, лежи у вишезначности продукције имиџа културе јер је он могао да понуди за свакога по нешто. У складу са трговачким концептом да „све има своју цену” произлази да „свака роба има свог купца" чије су потребе одређене тренутним и/или наслеђеним тежњама. Свака жена, независно од образовања, жели да буде задовољна својим изгледом и да се допадне свом партнеру. Он, опет, има потребу да поред себе има жену, мајку своје деце, самосталну и уједно зависну од њега, која задовољава актуелне друштвене естетске критеријуме. Да би ишли у корак са актуелним, ни за жену ни за мушкарца образовање није било предуслов. Под претпоставком да за остваривање поменутих примарних животних циљева може да буде предност, образовање није гарант за неусамљеност и задовољство. Свако ко ју је у том контексту знао да је искористи, имао је посебну привилегију да са издвојеног колосека посматра како пролази и нестаје композиција са луксузним производима српске културне индустрије деведесетих.

Није било једноставно одолети националном шоу ироіраму. Његов напредак, као и напредак културне индустрије, био је у рукама појединаца који су улагали сопствени капитал у еволуцију и прогрес нових појавних форми. С обзиром на то да је квалитет производње зависио од новца, оно „уметничко” постаје сасвим маргинално јер подразумева дозу етике и укуса који нису део забаве, па тиме ни део културе. Димензија уметничког није била потребна, па је нестала. Количина уложеног капитала, дакле, одређује потенцијал културне индустрије, а њен напредак је у том смислу неограничен, што значи да би и производ требало да буде скуп. Са робом културне индустрије то није случај, јер је намењена масовној потрошњи, јефтина је и само делује скупо јер се својим представама ослања на елементе луксуза и богатства.

Култура под бескрајним велом капитала постаје индустријска роба и као таква је парадоксална, јер је потпуно подређена закону размене, да се уопште више не размењује (Хоркхајмер-Адорно 1969:166).

Да ли је тако? Иако универзална културна размена јесте неопходна, посебно она симболичка, динамика феномена размене основни је покретач у адаптацији културе захтевима савременог друштва. Колико је таква прилагодљивост могућа показују и услови у којима се одигравала културна размена крајем деведесетих у Србији. Ратне 
околности нису спречиле развој тржишта индустрије културе, само су га усмериле у правцу привидне природне еволуције. У датим околностима роба је наставила да стиже до конзумента чије су потребе редуковане, па су тако и производи који никоме нису могли да буду испоручени ипак били прихваћени. Продавано је све дотрајало са рафова културне индустрије. Рекламиране су идеје које су припадале прошлости уз временом све јачи призвук традиције која се показала корисном у рукама индустријских моћника. Тако је пораст броја субвенционисаних идеолошких медија створио нови производ, посебан „стил” културне индустрије у којем значајно место заузима семантичка димензија. Пажљивом употребом речи у комбинацији са сликом и звуком остварен је потпуно другачији ниво комуникације који омогућава дисперзију идеолошких ставова кроз популарне форме лаке забаве. Музика, као једна од њих, нуди најшири манипулативни простор. Захваљујући високој концентрацији финансијске моћи, популарне песме се шире великом брзином и доносе нове феномене који то постају и пре но што се успоставе основни оквири у чијем пољу они делују. Речи на које се као успут додаје мелодија, само површно имају безазлени смисао. Можда несвесно креирана, културна политика популарног звука деведесетих у Србији веома је брзо успоставила правила функционисања. Непрестано понављање одабраних ликова јуначења, преко ноћи ствараних хитова резултирало је хиперпродукцијом значења, и све то у оквиру јединственог политичког идеолошког покрета, како је већ то антиципирано експерименталним идеолошко-музичким пројектом Иgоли. Привидно културно несналажење прикривено је магијом неразумљивог у којем је сваки грађанин као независан или део масе могао да пронађе нешто за себе. Условна слобода значила је одабир одређеног броја наметнутих вредности у начину понашања, разговора, облачења, живота. Слобода у избору идеологије показала се, међутим, као слобода за увек исто, у којем индивидуа својом вољом срозава природне потребе са циљем да постане пука имитација крутих модела културне индустрије.

Оваква појава на културној сцени била је предмет истраживања великог броја социолога, теоретичара културе, антрополога, политиколога и сваки закључак је водио у правцу личног и професионалног афинитета аутора. Тако су поједини аспекти турбо-фолка анализира- 
ни у ширем друштвено-политичком контексту, али су најчешће довођени у директну везу са тадашњим политичким режимом. Да ли је уопште нечији производ и ако јесте, чији је, није толико релевантно колико значењ $а$ која су се кроз њега провлачила. Широко семантичко поље привлачило је публику невероватном брзином и није било могуће одупрети му се. Супротстављени табори подељени на за и йро$\bar{u} и в$ били су, заправо, скоро подједнако важни учесници у креирању историје турбо-фолка.

У потрази за указивањем на механизме културне индустрије деведесетих, увек се враћамо значајном економско-идеолошки профиту. Не може се рећи да је музички укус нације после смрти Јосипа Броза остао неутралан и непоколебив. Музичка елита од Другог светског рата па све до осамдесетих година XX века имала је једног идеолошког вођу, а то је југословенски идентитет који је подразумевао национални диверзитет. Унификација на интелектуалном и културном пољу свакако је била један од императива за време Милошевићеве владавине. Разлог за потребом формирања монополистичког става делом лежи у друштвено-политичкој ситуацији у којој се нашла Србија краја XX века. Непостојање јасних државних и културних принципа условило је и кризу духа нације која се, у потрази са стабилношћу и сигурношћу, окренула привидима политичке модернизације и транзиције који су водили погубним историјским неспоразумима. Убрзо створено неповерење према свему што долази „изнутра” учинило је да се безусловно прихвата оно што се нудило „споља”. У таквом бестежинском простору на стабилне основе постављен је турбо-фолк. Његово ефикасно заузимање културне сцене помогао је државни апарат који није имао начина да се одупре увозу и наметању културних модела, а још мање идеју о томе како да се стваралачки понесе према сопственом културном наслеђу.

Иако је интервенција државе у почетку била очигледна, а „музички укус постао важан означитељ посебне режимске оријентације” (Горди 2001: 105), та веза је убрзо од непосредног добила посредан смисао, усмеравајући нови производ тамо где је уз велику подршку масе једино могао правилно да се развија - на сцену културне индустрије. Услови у којима је она функционисала били су одређени све већом изолацијом земље у европском мејнстриму, а која је изазивала 
све страснију жељу за подржавањем увезених модела у једном свету у коме технологија није допуштала никакве културне границе. Популарни народни звук постао је тако упориште оних идеја којима је народ похрлио у повратку и дефинисању сопственог лажног идентитета.

Даља анализа утемељена је на интерпретативној позицији да је турбо-фолк друштвено-културни френомен који је се исправно може тумачити идентификацијом његових конститутивних аспеката као и њихових могућих подпојава. Овај често називани феномен јесте поникао на темељима необичне социо-економске ситуације, али његов важан сачињавајући део јесу извођачи, шетајући имиџи који, иако се труде, не праве разлику између професионалног и приватног.

Општи утисак је да су певачице најчешће офарбане плавуше, оскудно обучене на западни начин. Под јаким рефлекторима, светлеће лопте наглашавају њихову славу, покривене су накитом, на високим штиклама, без трунке традиционалног у изгледу. Сав тај сјај крије и мрачну страну, што отвара простор за критички приступ целокупном имиџу турбо-фолк културе. Са једне стране, физички аспект је друштвени производ различитих социјалних услова, док са друге, те особине су резултат очекивања посматрача. Тела се појављују, дакле, формирана према очекивањима друштвене структуре (Бодријар, 1994: 64). Важно је да се жена у турбо-фолку посматра делом као отелотворени дискурс идеја у пост-комунистичком периоду у Србији. Жена је тако објективизирана и „посматрана”. Жене су, дакле, друштвено одређени објекти, а у популарној музици могу се прихватити као „мапе” за тумачење слике друштва и посредују у стварању идеологије популарног. У складу са идејом либералног тржишта, оне су само објекти помоћу којих се може увећати профит.

Бавећи се улогом жене у савременом филму, са аспекта феминистичких студија Малвеи (Mulvei) тврди да је, из родне перспективе, задовољство посматрача подељено на активног мушког и пасивног женског посматрача (Малвеи 1989: 14-26). Жена постаје предмет и фантазија мушког погледа. Према Малвеи, жена је она која иницира контакт, призива љубав или страх у свом мушкарцу - хероју, али се њој, ипак, не придаје много значаја (Малвеи 1989: 14-26). Тако жена има важну улогу посматраног објекта. Наступи жена на популарној 
сцени претварају се у визуелно задовољство и то је разлог што су јавни наступи и видео спотови погодан простор за остваривање идеолошких представа. Овакве сценске представе визуелног задовољства долазиле су заједно са заводљивим гласовима извођача.

Упркос очигледној деструкцији друштвено-културног система, владајућа реторика која се опрезно провлачила кроз турбо-фолк прећутно је прихватана као реална. Дискурс вестернизације нових идеја успешно је скриван иза бројних визуелних и лингвистичких националних представа које су се, као резултат свакодневног искуства, односиле истоврмено на масу и на појединца.

Тренутак у којем је српско друштво показало спремност да до краја изигра елементе традиције и прихвати их као основ за изградњу новог система увезених културних вредности јесте фарса венчања „бизнисмена" проблематичне криминалне прошлости и певачице српске популарне народне музике. Гламурозна фарса почела је у родном селу певачице и завршио се у Београду; сусрет на релацији село-град. Театрално су поштовани српски обичаји куповине младе, ношења вела преко лица пре венчања, преобуке младенаца у току свадбе, а посебно пуцњаве у ваздух као израза весеља; сусрет традиционално-насилно. У тренутку одвођења младе, младожења је у једној руци држао пиштољ а у другој Heckler\&Koch аутомат. Његова одећа је можда, више од свих других присутних традиционалних елемената, била индикатор стварања хибриднх вредности западног наоружања и традиционалних обичаја. Младожења није носио Заставино наоружање, јасно показујући одакле дувају ветрови рата. Обучен у војничку униформу са чиновима који су означавали највиши војни статус, младожења је имао масиван златни крст на својим грудима, прва асоцијација на религијски значај догађаја. Радило се о стварању новог мита и куповини угледа. Свештеник се младожењи обраћао са „војводо” приликом церемоније, а он је са понизним поштовањем у прикладним тренуцима обављања светог чина љубио крст. Приближавање западне војне технологије и националних обичаја изједначава западну културу, традиционално наслеђе и религијску симболику што, као својеврсни експолозивни Молотовљев коктел, доводи у питање саму државу.

Вештачки стечен углед намеће својство прикривања ствари онаквих каквим се показују и паралише суд посматрача (Лебон 2007: 
$82)$, те се слике и илузије прихватају као готов контекст. Значења која се у овој визуелној синтези документа и намере намећу јесу „густа и набијена великом количином суштине по квадратном сентиметру" (Бергер према: Вићентић 2011: 9). Површност, једноставност садржаја, насиље и еротичност утичу на стварање илузије о улози популарне музике деведесетих. Визуелни садржаји посебно подстичу имагинацију. Као идеја она се формира у свести појединца као учесника у гомили на бази информација о чудесним, легендарним, нестварним догађајима који представљају истинске оквире цивилизације (Лебон 2007: 41). Визуелни подаци најјаче утичу на масу јер, лишена могућности рационализације тренутка и информација, она може да расуђује само кроз представе и слике којима дозвољава да оставе утисак, ужасава је или постаје подстрек на даље акције (Лебон 2007: 41).

Значајна улога у дисперзији аудио-визуелног садржаја јесте у савременој технологији која не може бити посматрана одвојено од своје практичне и политичке употребе, па принцип остварења доминације садржаја не зависи од технологије већ развија сопствену технологију у рукама човека. Моћ машине је моћ човека, што модерном техничком и научном напретку омогућава да буде идеолошки манипулисан.

Спој две удаљене Србије, урбано укалупљене и мање урбане са више разумевања за склад с природом, богате и сиромашне, грубе и потенцијално наслине, славне и жељне славе, транзиционе и традиционалне, потврђивао је идентитет појединца на више нивоа нудећи могућност идентификације са аспектом најближим његовој личности. Овакве идеје потпуно одговарају колективној револуционарној свести младих, оних који заузимају критички став, али чији ум још није сасвим подлегао завођењу.

\section{Литература}

Клосковска 2005: Kloskovska, A. Sociologija kulture. Beograd: Čigoja. Кајтез 2006: Kajtez, N. Metafizika novca. Novi Sad: Topolino. Јањатовић 1998: Janjatović, P. IlustrovanaYUrockenciklopedija. Beograd: Geopoetika. 
Бодријар 1981: Baudrillard, J. For a critique of the political economy of the sign. Chapter V.St. Louis. Mo: Telos Press Ltd.

Вујаклија 2002: Вујаклија, М. Лексикон сиираних речи и израза. Београд: Просвета

Брехт 1979: Breht, B. Dijalektika u teatru. Beograd: Nolit. Sazvežđa

Хоркхајмер-Адорно 1969: Horkheimer, M - Adorno, T. Dijalektika prosvetiteljstva filozofijski fragmenti. Sarajevo: Svijetlost

Лебон 2007: LeBon, G. Psihologija gomila. Beograd-Gradac: ČačakAlef.

Горди 2001: Горди, Е. Кулииура властии у Србији. Београд. Самиздат Б92

Бодријар 1994: Baudrillard, J. Simulacra and Simulation. Michigan: University of Michigan Press

Малвеи 1989: Mulvei,L. (1989). Visual and other pleasures. Bloomington: Indiana University Press

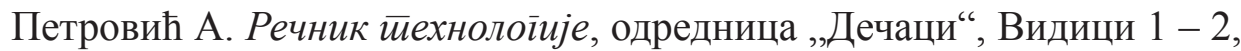
Београд 1981.

Vićentić 2011: Vićentić, N. „Umetnost beogradske novotalasne scene kao društveno politička intervencija." Zbornik radova Fakulteta dramskih umetnosti br. 17

Бергер http://recniktehnologije.wordpress.com/category/uvod-i-registar/

Mirjana B. Matović

\section{Summary}

\section{CULTURE INDUSTRY AND POPULAR CAPITAL}

This paper gives an analysis of the modern consumer society. When money becomes measure of all things, the cultural dynamics more and more begins to take shape of trading relationships. Due to that we have the overwhelming influence of the so-called popular, low culture, which is easier to advertise and sell, and which is because of that very profitable. In that context, high culture becomes financially independent on the low culture. Since the money exchanges are common to both, it means that culture is influenced by agents having no relations to it, such as industrialists, businessmen, or magnates. The paper furthermore points at the concrete example of Serbia in which the similar trend of commercialization had 
become rife, especially after Tito's death. Consumerist, low culture also played its role in the times preceding and during the disintegration of Yugoslavia, relating itself to the rising wave of nationalism.

Key words: high culture, low culture, money, consumerism, kitsch, nationalism 